Revista de Tecnología de Información y Comunicación en Educación • Volumen 15, Nㅜ 3. Septiembre-diciembre 2021

DOI: https://doi.org/10.46502/issn.1856-7576/2021.15.03.11

\title{
Digital instruments in educational activities
}

\section{Instrumentos digitales en actividades educativas}

\author{
Oksana A. Dubrova \\ okdubrova@yandex.ru \\ https://orcid.org/0000-0002-0295-9704 \\ Moscow State Institute of Culture, Moscow, Russia. \\ Inna K. Kirillova \\ innes_05-81@mail.ru \\ https://orcid.org/0000-0002-8506-0744 \\ Moscow State University of Civil Engineering, Moscow, Russia.
}

Anna I. Orlova

annasamurina@mail.ru

https://orcid.org/0000-0001-8708-6537

Nizhny Novgorod State Engineering and Economic University, Nizhny Novgorod,

Russia.

Anna A. Stryapikhina

anna-stryapikhina@rambler.ru

https://orcid.org/0000-0001-5837-8565

Nizhny Novgorod State Engineering and Economic University, Nizhny Novgorod,

Russia.

Sergey V. Semenov

svsemenov@gmail.com

https://orcid.org/0000-0001-5443-3600

Nizhny Novgorod State Engineering and Economic University, Nizhny Novgorod,

Russia.

\section{Abstract}

Recibido: $3 / 08 / 21$

Aceptado: 6/11/21

The objective of this article is analysis of the experience of implementing digital tools in educational activities and identifying the possibilities of modern digital tools in educational activities. Among the participants are students of higher educational institutions. The results allowed determining that Digital tools introduced and used in educational activities contribute to the training of a highly qualified specialist in demand in the labor market.

Key Words: gamification, educational process, higher educational institution, competencies, gaming technologies. 


\section{Resumen}

El objetivo de este artículo es un análisis de la experiencia de implementar herramientas digitales en las actividades educativas e identificar las posibilidades de las herramientas digitales modernas en las actividades educativas. Entre los participantes se encuentran estudiantes de instituciones de educación superior. Los resultados permitieron determinar que Las herramientas digitales introducidas y utilizadas en las actividades educativas contribuyen a la formación de un especialista altamente cualificado en la demanda del mercado laboral.

Palabras clave: gamificación, proceso educativo, institución de educación superior, competencias, tecnologías de juego.

\section{Introduction}

The modern educational environment is full of various electronic instruments. Many of them are rapidly becoming obsolete with the development of scientific and technological progress. At the same time, the task of professional educational institutions is to use the most relevant electronic tools that contribute to the training of a highly qualified specialist.

Tools that allow organizing joint activities for the implementation of various projects are in particular demand (Rudenko et al., 2021). The collective activity allows students to independently solve problematic issues, situations close to real professional conditions (Vaganova et al., 2019).

The joint processing of a large amount of information allows students to master the skill of communication and effective solutions of professional problems (Tsarapkina et al., 2021). Therefore, today visual collaboration is gaining special relevance (Aleshchanova et al., 2017).

Visual collaboration as a form of joint visual processing of a large amount of information in the form of drawings and pictures for subsequent decision making organizes interaction between the subjects to the educational process, which has great potential in achieving common goals (Yarygin et al., 2019). Students actively discuss issues, ideas, and share information with each other (Aniskin et al., 2020).

The management of many companies is based on the use of tools that facilitate active interaction (Pinkovetskaia et al., 2020). Therefore, in vocational training, for the best training of highly qualified specialists who can easily adapt to various professional conditions, visual collaborations are used (Nagovitsyn et al., 2020).

Considering electronic tools, it is necessary to pay attention to their basic functionality (Shashlo et al., 2018). 
Among the innovative digital tools, the Miro service should be noted. It is one of the most used tools both in the professional activities of various companies and in the professional training of students (Dobudko et al., 2019).

With corporate security and advanced administration tools, Miro can be deployed on a large scale.

\section{Theoretical framework}

The Miro service is visually an endless canvas. At the same time, it ensures that students remain motivated to complete tasks (Klimov et al., 2019). Miro has an intuitive interface (Vaganova et al., 2020). The interactive whiteboard can be used both in real time and in asynchronous mode (Shcerbakova \& Shcerbakova, 2019).

Miro integrates easily with the most popular tools (Pichugina \& Bondarchuk, 2019).

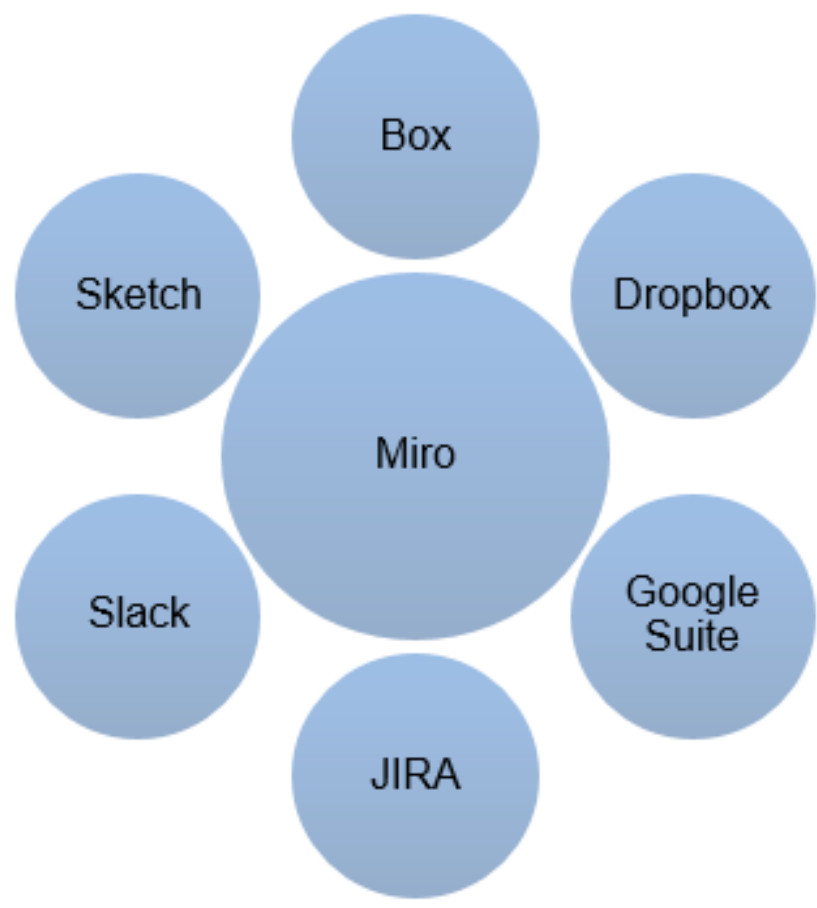

Fig. 1. Integration of Miro with various instruments

The picture shows an incomplete list of services that Miro can easily integrate with.

The Miro online platform allows you to maintain your privacy and security. At the same time, it is possible to add advanced security and compliance controls (Kharytonov et al., 2019). 
Miro allows you to organize remote work. Suitable for creating various projects, brainstorming. The uploaded files and documents are added to the board. Miro lets you draw, take notes and add different stickers (Ponachugin \& Lapygin, 2019).

Design is an integral part of the professional training of students (Misakov et al., 2019). The experience of implementing Miro's project activities shows that the activity becomes more effective, since the open flexibility of the service opens up new possibilities for creating any boards (Demidov et al., 2016b).

Mentimeter is worth noting among the popular digital tools used by universities to organize the educational process (Demidov et al., 2016a). This is an online service with which you can organize work with the audience using interactive forms online. Mentimeter provides ample opportunities:

- conducting surveys;

- holding a vote (Kiseleva et al., 2019);

- conducting quizzes;

- ask questions and receive feedback (Ivanova \& Korostelev, 2019).

The mentimeter is also used when presenting material in order to diversify the educational process (Bulaeva, et al., 2018).

The service is popular with students, including due to the lack of the need to use additional funds. To work, you need a computer, an output device (projector, monitor, screen) to broadcast the presentation.

For group projects, the Kahoot service is also used. It is a complete platform for educational games that allows you to create a game that meets the goals of a specific audience (Demidov et al., 2016b). The platform can be used without any special programming skills (Smirnova et al., 2020).

Kahoot includes a series of questions with a choice of the correct answer. Each Kahoot can be diversified by adding interactive elements (video clips, images, diagrams, etc.).

At the same time, it is possible to connect an unlimited number of participants to the game, who can use the service from a mobile phone, tablet or computer (Kidina, 2020).

E.N. Dronova reveals the technical side of the implementation of Kahoot properties (Dronova, 2020). The service includes several blocks that contain all the items necessary for the implementation of the game:

- home;

- discover;

- Kahoots; 
- Reports;

- Upgrade now;

- Create and others.

Each of the points is easy to use and allows students to quickly understand how to use the Kahoot service.

Kahoot includes many elements, the most commonly used ones are shown in the picture.

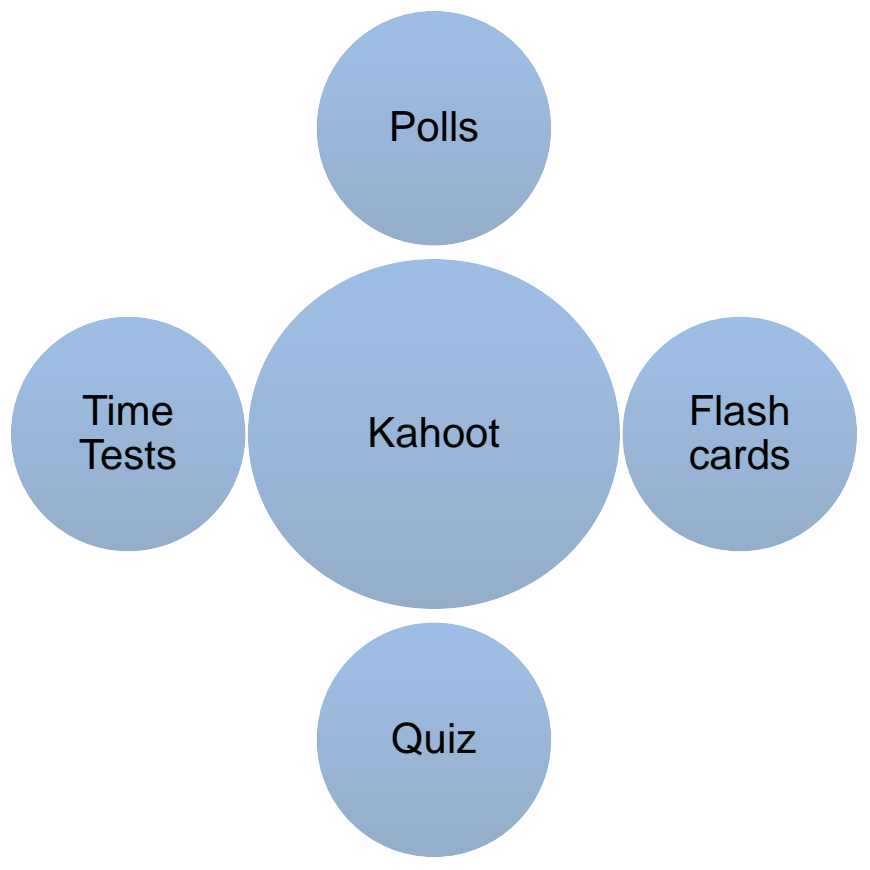

Fig. 2. Opportunities provided by the Kahoot service

Each of the services presented has ample opportunities for students to complete various tasks and organize the educational process in general.

\section{Methodology}

The study involved 355 students of higher educational institutions, including Moscow State Institute of Culture, Nizhny Novgorod State Engineering and Economic University.

The research is aimed at identifying the capabilities of the digital tools Miro, Mentimeter and Kahoot, adapted to work with large audiences of students. For this, control and experimental groups were allocated.

The study was conducted in several stages. At the first stage, students independently studied the capabilities of Kahoot and Miro services. We created surveys with the addition 
of pictures, photos and videos. The demonstration of the created surveys was carried out with the display on the screen in the classroom. In addition, students who do not have the possibility of full-time presence in the classroom entered a virtual room in which the task was reflected and a countdown was conducted for its solution. After completion, the results are displayed on the screen.

At the next stage, group work was organized, creating a quiz with developers of up to 30 people in one group.

The third stage involved the selection of the most relevant quizzes, which were accepted as official elements of the control of students' knowledge. At the end of the study of the topic, the selected quizzes were sent via mail to the participants of the educational process for its passage.

In the experimental groups, when preparing design work, students used the capabilities of the presented digital tools. Subsequent statistical processing of the data after the projects were defended made it possible to reveal the percentage of students who passed the project most successfully.

Research period: the academic year.

\section{Results and discussion}

Each of the subjects of the educational process using the Miro service has academic access to it, an academic account.

In the field of vocational education, project activities are very popular, which makes it possible to immerse the student to a greater extent in real professional conditions.

Therefore, the students carried out exactly the projects using various services.

The students interacted both remotely and directly in the classroom. We have identified two groups: control and experimental. Design in the control group took place without using the Miro service.

The research among students was carried out throughout the year.

The design was carried out using various electronic means of group interaction. The first figure shows the design results using the Miro service. 
Revista de Tecnología de Información y Comunicación en Educación • Volumen 15, N⒊ Septiembre-diciembre 2021

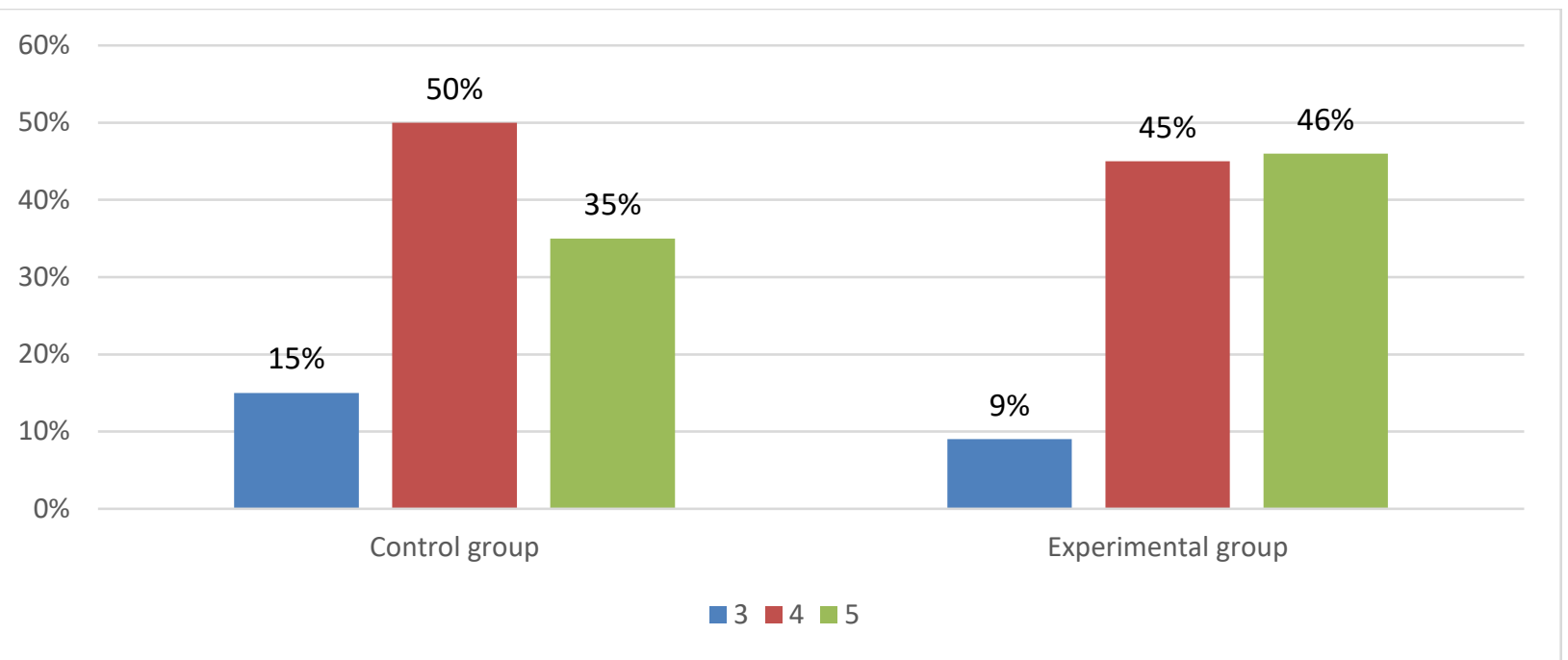

Fig. 3. Results of the control and experimental groups on the implementation of project activities using Miro.

We can observe that the results of the experimental group are higher than the control. Students completed the assignment faster. They were able to organize a high-quality independent process and active interaction.

The highest scores are observed in the experimental group.

Also, a service for conducting surveys in real time Mentimeter was introduced into the educational process. It has also been used by students during projects. The figure shows the results of the control and experimental groups.

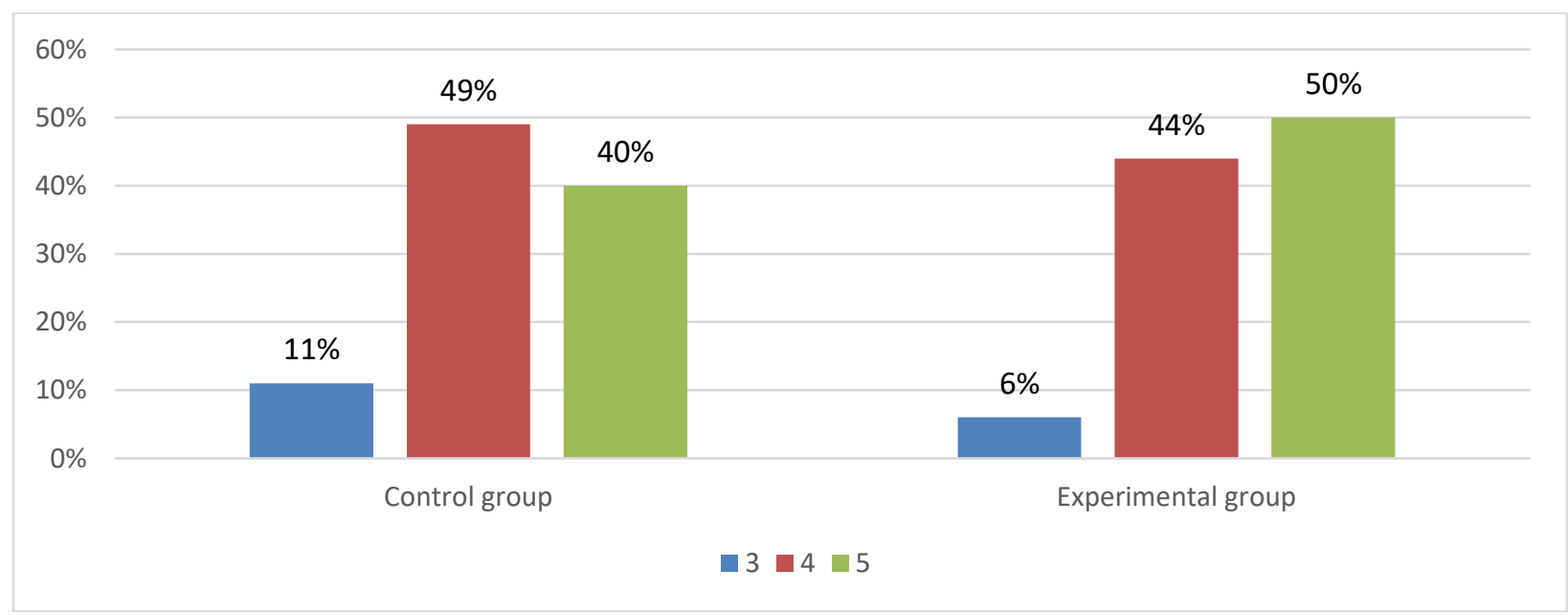

Fig. 4. Results of the control and experimental groups on the implementation of project activities using the Mentimeter. 
In the experimental group, using the Mentimeter service, the number of students with a high score is higher than in the control group.

Thanks to the use of the service, students have the opportunity to include a large number of respondents in their projects and work with large samples.

The results of using the Kahoot service are shown in the figure.

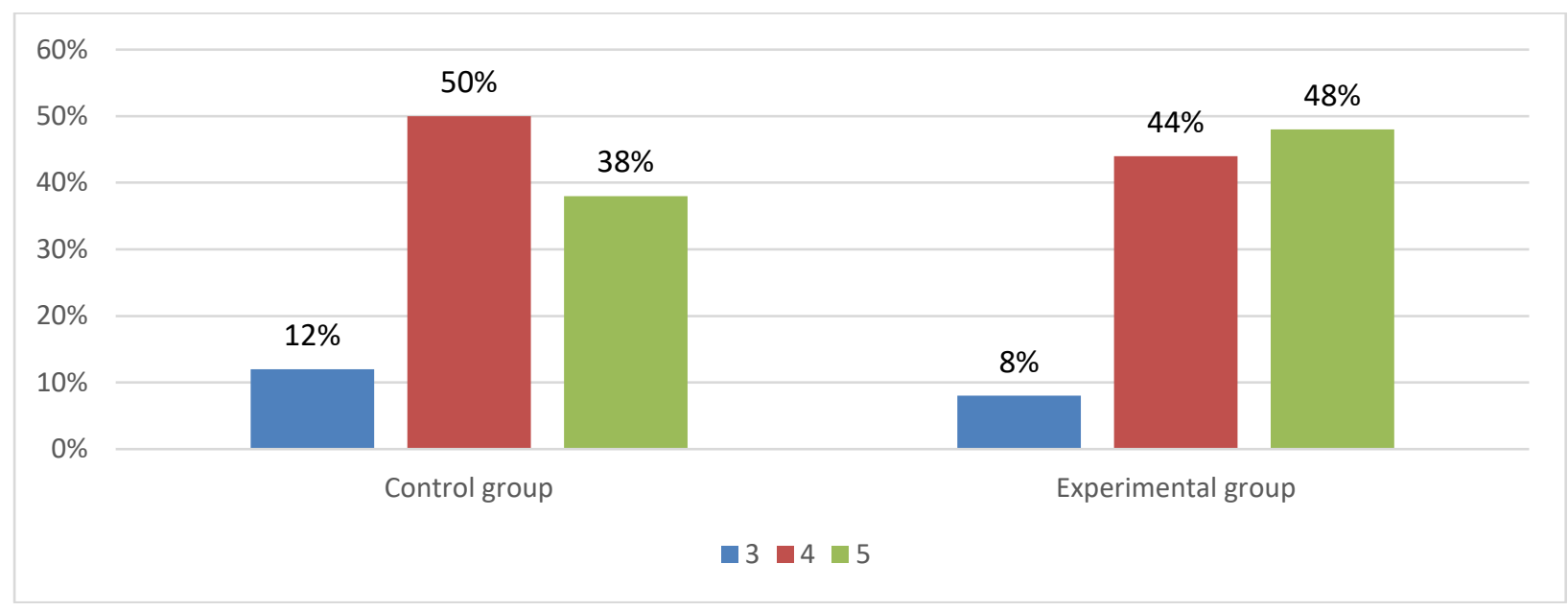

Fig. 5. Results of the control and experimental groups on the execution of project activities using Kahoot.

Games in real time or in the format of video conferencing in the Kahoot service, as the students themselves note, allow them to study the material deeper, motivate them to prepare for classes on their own and contribute to better problem solving.

Most of the students in the experimental group show high educational results. They easily solve various problems in a non-standard way and are ready for further professional selfimprovement.

In chat mode, students can exchange messages while using Miro. Collaboration cards in age format are a real tool. The teacher formulates the Problem. If it is large, then on the cards it is divided into subtasks, which are displayed on the board. The cards move around the board and reflect the stages of the progress of the work. Each of the teams participating in the project can make their own changes.

The Kahoot and Miro services used in the study contribute to a better organization of the educational process for both remote and full-time learning. The experience of using these services as modern electronic tools shows the effectiveness of their application. 


\section{Conclusions}

The digital tools used in the educational process of higher educational institutions are aimed at increasing the effectiveness of training and training competent highly qualified specialists.

Through the implementation of collective project activities through the services under consideration, students learn to independently interact and create the conditions necessary for themselves and their team to achieve the planned results.

The study made it possible to identify an increase in the effectiveness of the educational process through the use of electronic services. The participants in the experimental groups show better results compared to the control groups.

Among the results of the implementation of electronic tools, it is worth highlighting a high level of independence, active discussion of issues, activation of the cognitive and creative position of students, strengthening of the practical orientation of the educational process and the formation of experience in solving professional problems.

Experience with innovative electronic technologies during training allows students to increase their competitiveness in the labor market. Most modern enterprises use services that allow organizing the work of a large number of people with large amounts of information, services that automatically process results, and others. Experts who are fluent in the skills of using modern means of interaction can easily adapt to their professional activities.

Digital tools introduced and used in educational activities contribute to the training of a highly qualified specialist in demand in the labor market.

\section{Bibliographic references}

Aleshchanova, I.V., Frolova, N.A., Morozova, E.V., \& Zheltukhina, M.R. (2017). Psychological and Acmeological Aspect of Educational Cognitive Competence Development. In: Proceedings of the 7th International Scientific and Practical Conference Current Issues of Linguistics and Didactics: The Interdisciplinary Approach in Humanities (CILDIAH 2017). Advances in Social Science, Education and Humanities Research (ASSEHR), volume 97, 19-24.

Aniskin, V. N., Korostelev, A. A., Lvovna, B. A., Kurochkin, A. V., \& Sobakina, T. G. (2020). Teaching potential of integrated learning technologies Smart, Stem and Steam. Revista De La Universidad Del Zulia, 11(29), 328-336.

Arbeláez-Campillo, D., Tatsiy, V., Rojas-Bahamón, M., \& Danilyan, O. (2020). Contributions of critical thinking as a form of participation and political deliberation. Amazonia Investiga, 9(27), 5-12. https://doi.org/10.34069/Al/2020.27.03.1 
Bulaeva, M. N., Vaganova, O. I., Koldina, M. I., Lapshova, A. V., Khizhnyi, A.V. (2018). Preparation of Bachelors of Professional Training Using MOODLE. Advances in intelligent systems and computing, 622, pp. 406-411.

Dobudko, T.V., Kor ostelev A.A., Gorbatov S.V., Kurochkin A.V., \& Akhmetov L.G. (2019). The organization of the university educational process in terms of digitalization of education. Humanities and Social Sciences Reviews. 7(4), pp. 1148-1154.

Dronova, E.N. (2020). Elements of mobile learning in higher education: developing and conducting online surveys using the internet service Kahoot. Problems of modern education, (4), 196-208.

Demidov, A.A., \&Tretyakov, A.L. (2016a). A network model of centers for ethical and legal education and civil-patriotic education and media education centers based on school libraries: the need to create, opportunities and real prospects, Media Education (Mediaobrazovanie), 3, pp. 16-22.

Demidov, A.A., \& Tretyakov, A.L. (2016b) Centers for ethical and legal information and media education based on the school library - an innovation in the implementation of the Federal State Educational Standard and infrastructure for the development of information and legal culture of children and youth. Media Education (Mediaobrazovanie), 2, pp. 21-33.

Ivanova, N., \& Korostelev, A. (2019). The impact of competitive approach on students' motivation in sport. Amazonia Investiga, 8(18), 483-490. Retrieved from https://amazoniainvestiga.info/index.php/amazonia/article/view/362

Kidina I. M. (2020). Management of the pedagogical collective in the conditions of implementing distance learning. Baltic Humanitarian Journal. (Baltic Humanitarian Journal), Vol 9 No 4 (33), pp. 93-96.

Klimov A. A., Zarechkin E. Y., \& Kupriyanovsky V. P. (2019). About the digital ecosystem of a modern university. Modern Information Technology and IT Education, 15(4), 815-824.

Kharytonov, E., Kharytonova, O., Tolmachevska, Y., Fasii, B., \& Tkalych, M. (2019). Information Security and Means of Its Legal Support. Amazonia Investiga, 8(19), 255-265. https://amazoniainvestiga.info/index.php/amazonia/article/view/227

Kiseleva, O., Lebedev, A., Pinkovetskaia, I., Rojas-Bahamón, M., \& Arbeláez Campillo, D. (2019). Specialization and concentration of small and medium enterprises employees: Russian data. Amazonia Investiga, 8(20), 6-15. https://amazoniainvestiga.info/index.php/amazonia/article/view/59

Misakov, V., Tsurova, L., Yandarbayeva, L., Tkhamadokova, I., \& Gapurovna, G. (2019). Certification of A Regional Economic Complex as A Highly Effective Tool for analysis and diagnostics of its development. Amazonia Investiga, 8(20), 451-458. https://amazoniainvestiga.info/index.php/amazonia/article/view/174

Nagovitsyn, R. S., Vaganova, O. I., Kutepov, M. M., M. L. N., Kosenovich, O. V, Moeseev, Yu. V., Vorotova, M. S., \& Osipov, A. Y. (2020). Interactive Technologies in Developing Student's Motivation in Physical Education and Sport. International Journal of Applied Exercise Physiology, 9(6), 78-85.

Pichugina, G.A., \& Bondarchuk, A.I. (2019). Structure of the training case in the organization of the educational process. Humanitarian Balkan Research, 2(4), pp. 5-7. 
Pinkovetskaia, I., Berezina, N., \& Sverdlikova, E. (2020). The main reasons for the exit of entrepreneurs from business. Amazonia Investiga, 9(26), 68-73. https://doi.org/10.34069/Al/2020.26.02.7

Pinkovetskaia, I., Kryukova, L., Arbeláez, D., \& Rojas-Bahamon, M. (2019). Female Entrepreneurship: Types of Economic. Activity. Tarih kultur ve sanat arastirmalari dergisi-journal of history culture and art research, 8(2), 253-265. DOI: 10.7596/taksad.v8i2.2153

Ponachugin, A.V., \& Lapygin, Yu.N. (2019). Digital Educational Resources of the University: Design, Analysis and Expertise. Vestnik of Minin University, Vol. 7 (2), 5. (in Russ)

Rudenko, I. V., Bystrova, N. V., Smirnova, Zh. V., Vaganova, O. I., Kutepov, M. M. (2021). Modern technologies in working with gifted students. Propositos y representaciones, 9. № SI, Article number e818.

Shashlo, N., Petruk, G., \& Korostelev, A. (2018). Determinants of integration interaction among the subjects of the entrepreneurial innovation ecosystem of macro region. Amazonia Investiga, $\quad 7(13), \quad 351-363$. https://amazoniainvestiga.info/index.php/amazonia/article/view/569

Smirnova, Z.V., Vezetiu, E.V., Vaganova, O.I., Pluzhnikova, E.A., Akimova, I.V. (2020). Automated knowledge management through e-testing. International Journal of Advanced Trends in Computer Science and Engineering, 9(3), pp. 3256-3260.

Shcerbakova E.V., \& Shcerbakova T. N. (2019). Experience of Use of Remote Computer Technologies at The Organization of Independent Work of Students in The Conditions of a Mark and rating system. Baltic Humanitarian Journal. (Baltic Humanitarian Journal). Vol. 8, No 4 (29), pp. 192-195.

Tsarapkina, J. M., Plahina, L. N., Konoplyuk, N. V., Vaganova, O. I., \& Lapshova, A. V. (2021). The formation of bachelors' digital competencies at the university. Propositos y representaciones, 9, № SI, Article number e811.

Vaganova, O.I., Korostelev, A.A., Smirnova, Z.V., Abramova, N.S., \& Dolmatov, S.N. (2019). Improving teachers' professionalism through the development of creativity. International Journal of Innovative Technology and Exploring Engineering, 8(8), pp. 630-634.

Vaganova, O. I., Petrozitskaya, I. A., Snatovich, A. B., Odarich, I. N., \& Kirillova, I. K. (2020). Heuristic technologies of training in professional education. Amazonia Investiga, 9(27), 509-517. https://doi.org/10.34069/Al/2020.27.03.55

Yarygin, O.N., Korostelev, A.A., Akhmetov, L.G., \& Maseleno, A. (2019). Modeling of competence as a tool of goal setting for education in modern society. International Journal of Recent Technology and Engineering, 7(6), pp. 72-77. 